\section{Legionella Native Valve Endocarditis Case Report and Review of Literature}

\title{
Abstract
}

Background: Legionella native valve endocarditis is exceedingly rare, and to the best of our knowledge, this is the first case complicated by a septic spleen infarction.

\section{Keywords}

Legionella; Endocarditis; Pneumonia; Septic Embolism.

\section{Introduction}

The incidence of infectious endocarditis worldwide is estimated at 30/100.000 cases per year. In Western Europe and North America endocarditis on native valves show an incidence of 2-6/100.000 per year $[1,2]$. Streptococcus and Staphylococcus species are the cause for endocarditis in about 80\%, another 10\% are caused by Enterococcus species or bacteria of the HACEK-group. According to Barnes et al. culture negative endocarditis accounts for 2.5 to $31 \%$ of all cases [3]. Negative blood cultures often result from previous antimicrobial therapy or fastidious bacteria (mostly Coxiella burnetti, Bartonella spp. And Tropheryma whippeli).

Legionella species are very rarely found as causative agent of infectious endocarditis; only 2 patients with involvement of a native valve are mentioned in literature so far. Legionella species are fastidious gram-negative bacilli. Today 57 species are known incorporating at least 79 different serotypes. According to Murder and Yu 20 different Legionella species are considered as pathogens for humans, of which Legionella pneumophila is responsible for $90 \%$ of infections [4]. Legionella pneumophila has 16 serotypes, with serotype 1 being the most significant, other Legionella serotypes are found in nosocomial infections. Legionella mostly causes pneumonia by direct

Verena Baumgartner ${ }^{1}$, Gerhard Eich², Stefan Christen ${ }^{3}$, Corinne Chmiel ${ }^{4}$

1 Division of Internal Medicine, City Hospital Waid, Zurich, Switzerland.

2 Division of Infectiology, City Hospital Triemli, Zurich, Switzerland.

3 Division of Cardiology, City Hospital Waid, Zurich, Switzerland.

4 Division of Internal Medicine, City Hospital Waid, Zurich, Switzerland and University Hospital Zurich, Institute of Primary Care, University of Zurich, Switzerland.

\section{Contact information:}

Corinne Chmiel.

PD Dr. med.

Address: University Hospital Zürich, Institute of Primary Care, University of Zurich, Pestalozzistrasse 24, CH-8091 Zürich, Switzerland.

Tel: 0041442559855.

Fax: 0041442559097.

झ corinne.chmiel@usz.ch 
inhalation of contaminated aerosol [5]. Extra pulmonary manifestations are rare and described predominantly in surgical patients as prosthetic valve endocarditis, joint-prosthesis- or wound-infections [6], where the infection pathway is via inoculation with the bacteria during surgery. Gold standard for diagnosis of Legionella pneumonia is a positive culture on a Legionella- BCYE-Agar or a LegioneIla specific PCR. Since these diagnostic methods are complex and not always available, the most commonly performed testing is the detection of Legionella antigen in the urine, even though the test is only able to detect Legionella pneumophila serotype 1. Serological testing is not useful for diagnosing acute infection since seroconversion often occurs only after several weeks. Final proof of a Legionella endocarditis is a positive histology with typical bacteria seen on electronic microscopy or a positive PCR for Legionella.

\section{Methods and Findings}

\section{Case report and review of literature}

A 64 year old man with alcoholic liver cirrhosis (Child A) presented with a few weeks' history of fever, dyspnea, cough and thoracic pain. His previous medical history was uneventful and medication intake was reported. On admission he was febrile $\left(40.0^{\circ} \mathrm{C}\right)$, had a heart rate of $115 / \mathrm{min}$ and a blood pressure of $120 / 80 \mathrm{mmHg}$. His respiratory rate was $35 / \mathrm{min}$, the oxygen saturation breathing room air was $91 \%$. The pulmonary examination revealed diminished lung sounds and crackles in the right lower lobe. Heart sounds were normal and there were no murmurs. The electrocardiogram showed a new atrial fibrillation. Leucocytes were at $9.5 \mathrm{G} / \mathrm{l}$ (normal range 3.5-10.0 G/l) with a marked left shift (36\%), C-reactive protein (CRP) was highly elevated at $333 \mathrm{mg} / \mathrm{l}$ (normal range $<5 \mathrm{mg} / \mathrm{l})$, and serum creatinine was $117 \mu \mathrm{mol} / \mathrm{l}$ (normal range 62-106 $\mu \mathrm{mol} / \mathrm{l}$ ). Urinary spot analy-

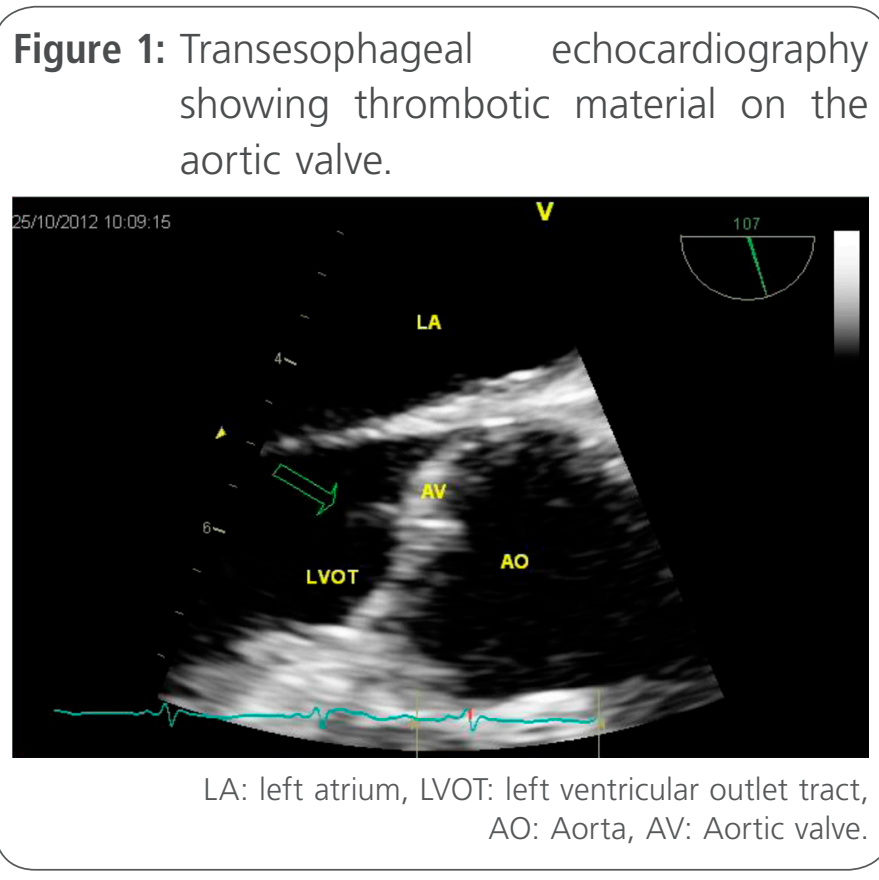

sis showed microhematuria $>10 \mathrm{mg} /$ (normal range $<0.3 \mathrm{mg} / \mathrm{l}$ ) and proteinuria of $1 \mathrm{~g} / \mathrm{l}$ (normal range $<0.1 \mathrm{~g} / \mathrm{l})$. An extensive infiltration of the entire right lung was seen on chest X-ray. Community acquired pneumonia was diagnosed and empiric antibiotic treatment with ceftriaxone and clarithromycin initiated. After five days the patient's condition significantly improved and clarithromycin was stopped. After a transient improvement, the patient's inflammatory parameters again deteriorated, and he developed respiratory failure accompanied by delirium tremens. A right basal lung abscess and two fresh spleen infarctions were diagnosed in the thoraco-abdominal CT scan. Transthoracic echocardiography revealed a $6 \mathrm{~mm}$ floating thrombus on the aortic valve, which was confirmed by transesophageal echocardiography (Figure 1). According to the Duke criteria (1 major, 4 minor criteria) diagnosis of culture negative endocarditis with suspicion of septic embolisms was made. The urinary test result for Legionella antigen was positive and antibiotic therapy with clarithromycin was restarted. Consecutively, a Legionella antibody analysis of the serum by complement binding reaction was performed showing a slightly positive result. Repetitive blood cultures, specific PCR 
for Legionella as well as conventional culture of the pleural fluid remained negative, as did Brucella serology. Consecutively, the patient's pulmonary and cardiac status steadily improved. Twenty days after admission the patient was transferred to an alcohol rehabilitation institution. After a total of six weeks antibiotic treatment with clarithromycin the patient was seen for follow-up. He presented in good clinical condition with normalization of the chest X-ray and laboratory parameters. The repeated analysis of Legionella specific PCR and broad spectrum PCR of the serum were negative. Legionella urinary antigen analysis remained positive. Although transthoracic echocardiography still showed some valve abnormalities interpreted as residual scars, we decided to stop the antibiotic treatment. At follow up three months later the patient was well and asymptomatic.

\section{Discussion}

The current case is, to the best of our knowledge, the first report of an endocarditis due to Legionella complicated by a spleen abscess. Altogether, it represents the third report of a native valve endocarditis attributable to Legionella pneumophila (Table 1).

Legionella endocarditis has rarely been described in literature. Only 16 cases have been reported from which the first is dated to 1984 [7]. In almost all cases patients had experienced valve surgery, only two other cases besides ours had native valves [8, 9]. In our case the urinary und serum analyses for Legionella antigen was positive, but specific PCR for Legionella as well as was broad spectrum PCR showed repeatedly negative results. In literature only in one patient the diagnosis was confirmed with PCR and sequencing from aortic tissue [9], in the other, Legionella pneumophila serotype 1 was detected in the urine sample and cultures on buffered charcoal-yeast extract (BCYE)-Agar using blood and bronchial fluid [8].
Admission diagnosis of our patient was pneumonia and antibiotic treatment with Ceftriaxone and Clarithromycin was started. Since ceasing the therapy with Clarithromycin was followed by serious deterioration of the patient's state, we assumed systemic spreading of the bacteria. Diagnosis of endocarditis was established by Duke criteria fulfilling 1 major criteria by positive transesophageal echocardiography (Figure 1) with a floating mass on the aortic valve, as well as 4 minor criteria: fever (temperature $>38^{\circ} \mathrm{C}$ ), vascular phenomena (lung and spleen infarction), immunological phenomena (nephritic syndrome) and microbiological evidence (positive urinary antigen for Legionella pneumophila serotype 1 and positive blood serology).

Embolic events due to Legionella endocarditis seem to be very rare and have been reported in only two other cases with valve-prosthesis infection [10, 11]. Our patient showed two fresh spleen infarctions diagnosed in thoraco-abdominal CT scan. Whether they were caused by septic or thrombotic cardiac embolism triggered by the paroxysmal atrial fibrillation is not certain, the lack of other thrombotic material in transthoracic and transesophageal echocardiography other than the floating vegetation on the aortic valve as well as the presence of immunological phenomena (e.g. nephritic syndrome) seem to favor septic embolism as a cause.

Regarding the duration of therapy for Legionella endocarditis evidently no guidelines exists. Therapy regimens ranging from six weeks for native valves [8] to 5-14 months for prosthetic valves [10, 12] have been described in literature (Table 1).

\section{Conclusion}

In case of culture negative endocarditis Legionella species has to be thought of as possible causative agent, particularly in patients with prosthetic valves. Embolic events in Legionella endocarditis are extremely rare, but have been reported. Molecular proof of the bacteria with PCR respectively silver 
Table 1. Literature Review Legionella Endocarditis (all Case Reports).

\begin{tabular}{|c|c|c|c|c|c|c|c|c|}
\hline Case & Author & Year & Valve type & Diagnosis & $\begin{array}{l}\text { Patient characteristics/ } \\
\text { risk factors }\end{array}$ & Treatment & $\begin{array}{l}\text { Complications/ } \\
\text { outcome }\end{array}$ & Pathogen \\
\hline 1 & $\begin{array}{l}\text { McCabe R E } \\
\text { et al. }\end{array}$ & 1984 & pr, po, a, m & $\begin{array}{l}\text { Valve culture, } \\
\text { serology }\end{array}$ & $\begin{array}{c}\text { W, } 60 \text { y, rheumatic valvular } \\
\text { disease }\end{array}$ & $\begin{array}{c}\text { ERM for } 6 \text { mo, RIF for } 2 \text { mo - valve } \\
\text { replacement }\end{array}$ & Cured & L. Pneumophila \\
\hline 2 & $\begin{array}{l}\text { Tompkins } L \\
\text { S et al. }\end{array}$ & 1988 & pr, po, a, m & $\begin{array}{l}\text { Valve culture, } \\
\text { serology }\end{array}$ & $\begin{array}{l}\text { Valve surgery at sumc during } \\
\text { a general outbreak of I. }\end{array}$ & $\begin{array}{l}\text { ERM } 4 \mathrm{~g} \text { iv for } 8 \text { wk, } 2 \mathrm{~g} \text { po for } 12 \\
\text { mo, RIF } 600 \text { mg po for } 6 \text { mo - valve } \\
\text { replacement }\end{array}$ & $\begin{array}{l}\text { Cured at } 48 \\
\text { mo follow up }\end{array}$ & L. Pneumophila \\
\hline 3 & $\begin{array}{l}\text { Tompkins } L \\
\text { S et al. }\end{array}$ & 1988 & pr, po, a & $\begin{array}{l}\text { Valve culture, } \\
\text { serology }\end{array}$ & $\begin{array}{l}\text { Valve surgery at sumc during } \\
\text { a general outbreak of I. }\end{array}$ & $\begin{array}{c}\text { ERM } 4 \mathrm{~g} \text { iv for } 6 \mathrm{mo} \text {, RIF } 600 \mathrm{mg} \text { po } \\
\text { for } 6 \text { mo, vancomycin } 2 \mathrm{~g} \text { iv for } 6 \mathrm{mo} \text { - } \\
\text { valve replacement }\end{array}$ & $\begin{array}{l}\text { Cured at } 40 \\
\text { mo follow up }\end{array}$ & L. Dumoffii \\
\hline 4 & $\begin{array}{l}\text { Tompkins L } \\
\text { S et al. }\end{array}$ & 1988 & pr, me & Serology & $\begin{array}{l}\text { Valve surgery at sumc during } \\
\text { a general outbreak of I. }\end{array}$ & $\begin{array}{c}\text { ERM } 4 \mathrm{~g} \text { iv for } 2 \mathrm{mo}, 2 \mathrm{~g} \text { po for } 6 \mathrm{mo} \\
\text { RIF } 600 \mathrm{mg} \text { po for } 6 \mathrm{mo}\end{array}$ & Cured & L. Pneumophila \\
\hline 5 & $\begin{array}{l}\text { Tompkins L } \\
\text { S et al. }\end{array}$ & 1988 & pr, po, a & $\begin{array}{l}\text { Valve culture, } \\
\text { serology, blood } \\
\text { culture }\end{array}$ & $\begin{array}{l}\text { Valve surgery at sumc during } \\
\text { a general outbreak of I. }\end{array}$ & $\begin{array}{c}\text { ERM } 2 \text { g iv for } 9 \text { mo, RIF } 1200 \mathrm{mg} \text { po } 9 \\
\text { mo- valve replacement }\end{array}$ & $\begin{array}{l}\text { Cured at } 11 \\
\text { mo follow up }\end{array}$ & L. Dumoffii \\
\hline 6 & $\begin{array}{l}\text { Tompkins L } \\
\text { S et al. }\end{array}$ & 1988 & pr, po, m & $\begin{array}{l}\text { Valve culture, } \\
\text { serology, blood } \\
\text { culture }\end{array}$ & $\begin{array}{l}\text { Valve surgery at sumc during } \\
\text { a general outbreak of I. }\end{array}$ & $\begin{array}{l}\text { ERM } 3 g \text { iv for } 5 w k \text {, followed by ERM } \\
4 \mathrm{~g} \text { iv for } 1 \mathrm{mo} \text {, followed by } 2 \mathrm{~g} \text { po } \\
\text { and RIF } 600 \mathrm{mg} \text { po for } 14 \mathrm{mo} \text { - valve } \\
\text { replacement }\end{array}$ & Cured & L. Dumoffii \\
\hline 7 & $\begin{array}{l}\text { Tompkins L } \\
\text { S et al. }\end{array}$ & 1988 & pr, po, m & $\begin{array}{l}\text { Blood culture, } \\
\text { serology }\end{array}$ & $\begin{array}{l}\text { Valve surgery at sumc during } \\
\text { a general outbreak of I. }\end{array}$ & $\begin{array}{l}\text { ERM } 4 \mathrm{~g} \text { iv for } 2 \text { days, followed } \\
\text { by Ciprofloxacin } 600 \mathrm{mg} \text { iv and } \\
\text { RIF } 1200 \mathrm{mg} \text { po for } 10 \mathrm{wk} \text { - valve } \\
\text { replacement }\end{array}$ & $\begin{array}{l}\text { Development of mitral } \\
\text { insufficiency }\end{array}$ & L. Pneumophila \\
\hline 8 & $\begin{array}{l}\text { Tompkins L } \\
\text { S et al. }\end{array}$ & 1988 & pr, po & $\begin{array}{l}\text { Blood culture, } \\
\text { serology }\end{array}$ & $\begin{array}{l}\text { Valve surgery at sumc during } \\
\text { a general outbreak of I. }\end{array}$ & $\begin{array}{l}\text { ERM } 4 \mathrm{~g} \text { iv for } 2 \text { mo plus RIF } 1200 \mathrm{mg} \\
\text { po for } 5 \text { mo }\end{array}$ & Cured & $\begin{array}{l}\text { L. Pneumophila, } \\
\text { I. Dumoffii }\end{array}$ \\
\hline 9 & $\begin{array}{l}\text { Park D } \\
\text { et al. }\end{array}$ & 1994 & pr, me, a & Serology & MI, 65 y, diabetic & Doxycyclin - valve replacement & Microscopic hematuria & L. Micdadei \\
\hline 10 & $\begin{array}{l}\text { Chen TT } \\
\text { et al. }\end{array}$ & 1996 & pr, me, a & $\begin{array}{l}\text { Valve culture, blood } \\
\text { culture }\end{array}$ & Ml, 33 y, marfan syndrome & ERM for 6 mo, RIF - valve replacement & Pseudoaneurysm & L. Pneumophila \\
\hline
\end{tabular}




\begin{tabular}{|c|c|c|c|c|c|c|c|c|}
\hline Case & Author & Year & Valve type & Diagnosis & $\begin{array}{l}\text { Patient characteristics/risk } \\
\text { factors }\end{array}$ & Treatment & $\begin{array}{l}\text { Complications/ } \\
\text { outcome }\end{array}$ & Pathogen \\
\hline 11 & $\begin{array}{l}\text { R. Massey } \\
\text { et al. }\end{array}$ & 2003 & $\mathrm{pr}, \mathrm{h}, \mathrm{a}$ & $\begin{array}{c}\text { Valve cultures } \\
\text { negative after } \\
\text { prolonged antibiotic } \\
\text { treatment, l. } \\
\text { Pneumonia } \\
\text { microbiologically } \\
\text { confirmed (method } \\
\text { not further specified) }\end{array}$ & $\begin{array}{c}\text { Ml, } 26 \text { y, congenital heart } \\
\text { disease, I. Pneumonia during } \\
\text { a localized outbreak }\end{array}$ & $\begin{array}{l}\text { Clarithromycin, RIF iv - repeat valve } \\
\text { replacement }\end{array}$ & $\begin{array}{l}\text { Microembolism of } \\
\text { digits, respiratory } \\
\text { failure, dic }\end{array}$ & L. Pneumophila \\
\hline 12 & $\begin{array}{l}\text { Patel MC } \\
\text { et al. }\end{array}$ & 2005 & $p r, b, a$ & Valve culture & $\begin{array}{c}\text { Ml, } 63 \text { y, kidney } \\
\text { transplantation, history of } \\
\text { hodgkin`s disease }\end{array}$ & $\begin{array}{l}\text { Levofloxacin indefinitely - valve } \\
\text { replacement }\end{array}$ & No relapse & L. Micdadei \\
\hline 13 & $\begin{array}{l}\text { Samuel V } \\
\text { et al. }\end{array}$ & 2011 & native & $\begin{array}{l}\text { Blood culture, bal, I. } \\
\text { Antigen urine test }\end{array}$ & $\begin{array}{l}\text { W, } 42 \text { y, corticosteroids for } \\
\text { pneumonitis }\end{array}$ & Levofloxacin for 6 wk, RIF for 6 wk & $\begin{array}{l}\text { Pneumonia, ards, dic, } \\
\text { septic shock, acute } \\
\text { kidney injury with } \\
\text { hemodialysis, cured }\end{array}$ & L. Pneumophila \\
\hline 14 & $\begin{array}{l}\text { M. M. } \\
\text { Pearce et al. }\end{array}$ & 2011 & native & Valve culture & $\begin{array}{c}\text { W, } 68 \text { y, good pasture } \\
\text { syndrome, kidney } \\
\text { transplantation, cmv infection }\end{array}$ & $\begin{array}{l}\text { (Penicillin allergy) Vancomycin, } \\
\text { Ciprofloxacin, Gentamycin - valve } \\
\text { replacement - after positive culture } \\
\text { Moxifloxacin for } 6 \text { wk - relapse: } \\
\text { vancomycin, RIF Azithromycin, valve } \\
\text { replacement was refused }\end{array}$ & Death & $\begin{array}{c}\text { New I. Strain, } \\
\text { designated } \\
\text { h63, shares the } \\
\text { highest similarity } \\
\text { with I. Brunensis }\end{array}$ \\
\hline 15 & $\begin{array}{c}\text { Yuriko } \\
\text { Fukuta et al. }\end{array}$ & 2012 & pr, me, m & Valve culture & $\begin{array}{l}\text { W, } 57 \text { y, sle and } \\
\text { anti-phospholipid-sydnrom, } \\
\text { corticosteroids, azathioprin }\end{array}$ & $\begin{array}{l}\text { Levofloxacin for } 5 \text { mo - valve } \\
\text { replacement }\end{array}$ & $\begin{array}{l}\text { Brain abscess, after } \\
5 \text { mo of therapy } \\
\text { persistence of frontal } \\
\text { brain mass, therapy was } \\
\text { continued (duration } \\
\text { unknown) }\end{array}$ & L. Micdadei \\
\hline 16 & our case & 2013 & native & $\begin{array}{l}\text { L. Antigen urine test, } \\
\text { serology }\end{array}$ & $\begin{array}{l}\text { Ml, } 64 \text { y, alcoholic liver } \\
\text { cirrhosis, I. Pneumonia }\end{array}$ & Clarithromycin for 6 wk & $\begin{array}{l}\text { Spleen infarction, cured } \\
90 \text { mo follow up }\end{array}$ & L. Pneumophila \\
\hline
\end{tabular}

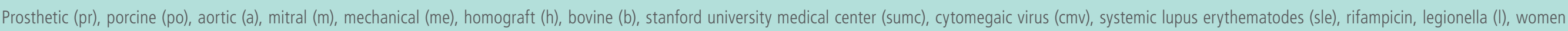
$(\mathrm{f})$, male $(\mathrm{ml})$, years (y), cytmoegalic virus (cmc), broncho alveolar lavage (bal), inveravenous (iv), peroral (po), months (mo), weeks (wk), disseminated intravascular coagulopathy (dic) 
impregnation stains from histological material are desirable, but unfortunately histological material is not always available.

\section{Potential conflicts of interest}

All authors declare no conflict of interests. All authors have submitted the ICMJE Form for Disclosure of Potential Conflicts of Interest.

\section{References}

1. Hogevik $\mathrm{H}$, et al. Epidemiologic aspects of infective endocarditis in an urban population. A five-year prospective study. Medicine 1995; 74: 324.39

2. Berlin JA, Abrutyn E, Strom BL, Kinman JL, Levison ME, Korzeniowski OM, et al. Incidence of infective endocarditis in the Delaware Valley, 1988-1990.

3. Barnes PD, Crook DWM. Culture negative endocarditis. J Infect 1997: 35: 209.13.

4. Robert R. Muder and L. Yu Victor. Infection Due to Legionella Species Other Than L. pneumophila.Clin Infect Dis. (2002) 35 (8): $990-998$

5. Carratalà J, Garcia-Vidal C. An update on Legionella. Curr Opin Infect Dis 2010; Apr; 23(2): 152-7.

6. Lowry PW, Tompkins LS. Nosocomial legionellosis: a review of pulmonary and extrapulmonary syndromes. 1993 Feb; 21(1): 21-7.

7. Prendergast BD. Diagnosis of infective endocarditis. BMJ. 2002 Oct 19; 325(7369): 845-6.

8. Samuel V., Bajwa A. A., Cury J. D. First case of Legionella pneumophila native valve endocarditis. Int J Infect Dis. 2011 Aug; 15(8): e576-7.

9. N. Theodoropoulos, G. A. Noskin, J. P. Flaherty. Native Valve Endocarditis Due to a Novel Strain of Legionella. J Clin Microbiol. 2011 September; 49(9): 3340-3342.

10. Yuriko Fukuta, Isil Z. Yildiz-Aktas, A. William Pasculle \& Peter J. Veldkamp. Legionella micdadei prosthetic valve endocarditis complicated by brain abscess: Case report and review of the literature. Scandinavian Journal of Infectious Diseases, 2012; 44: 414-418.

11. R. Massey, P. Kumar, J. Pepper. Innocent victim of a localized outbreak: legionella endocarditis. Heart. 2003 May; 89(5): e16.

12. Brouqui P, Raoult D. Endocarditis due to rare and fastidious bacteria. Clin Microbiol Rev 2001; 14: 177-207.
Publish in International Archives of Medicine

International Archives of Medicine is an open access journal publishing articles encompassing all aspects of medical science and clinical practice. IAM is considered a megajournal with independent sections on all areas of medicine. IAM is a really international journal with authors and board members from all around the world. The journal is widely indexed and classified Q1 in category Medicine. 